\title{
A Welsh record of an Anglo-Saxon political mutilation
}

\author{
ELIZABETH BOYLE
}

\begin{abstract}
A previously unidentified annal-entry in the Welsh chronicles Brut y Tyysogion and Brenbinedd y Saesson records the blinding of the sons of Ealdorman Elfhelm as part of the 'palace revolution' of 1006. This article discusses how the Old English names Wultheah and Ufegeat were recorded by Welsh scribes in accordance with Welsh phonological and orthographical norms. Possible Anglo-Saxon sources for the annal-entry are briefly considered and the transmission of the annal-entry in the Welsh sources is analysed.
\end{abstract}

In the annal-entry which Thomas Jones assigned to 1004 in his editions of the Welsh translations of Annales Cambriae, we read the following.

(P) Y dallwyd Gwlfach ac Vbiad. ${ }^{1}$

(M) Ac y dallwyt Gwlfac ac Vryat. ${ }^{2}$

(S) Y dallwt Gulfach ac Vbiat. ${ }^{3}$

'[And] Gwlfach and Ubiad were blinded.'

Neither the texts nor modern scholars have stated the identities of the victims of this blinding. Welsh chronicles contain many references to blindings, castrations, kin-slayings and other brutal acts. These are recorded particularly in relation to the twelfth century, but they usually occurred as part of a larger internecine feud, often committed by royals on their close relatives. However, I do not think that this chronicle-entry refers to a Welsh mutilation. One reason is that these names do not appear in any Welsh genealogies and seem not to be of native Welsh origin. Indeed, the inherent foreignness of both Gwlfach and Viat are indicated by the first syllable; no disyllabic or polysyllabic native word would have had $/ \mathrm{u} /$ in the first syllable, as originally unaccented $/ \mathrm{u} /$ would have been

${ }^{1}$ Brut ) Tymysogyon Peniarth MS. 20, ed. T. Jones (Cardiff, 1941), p. 13, (s.a. 1003); the date was wrongly assumed to be connected to 1004 rather than 1006 in Bruty Tymysog)on or The Chronicle of the Princes, Peniarth MS. 20 Version, trans. T. Jones (Cardiff, 1952), p. 11 (cf. p. lxix for the internal evidence which would have permitted correction, and p. 148, n. 11:8).

${ }^{2}$ Mostyn MS 116, Brut y Tywysogyon or The Chronicle of the Princes, Red Book of Hergest Version, ed. and trans. T. Jones (Cardiff, 1955; 2nd ed., 1973), pp. 18-19 (s.a. [1004], but datable only 1000 $\times 1010$ ); cf. p. 280 (n. 19:32).

${ }^{3}$ Brenhinedd y Saesson or The Kings of the Saxons, BM Cotton MS. Cleop atra Bv and The Black Book of Basingwerk NLIV MS. 7006, ed. and trans. Thomas Jones (Cardiff, 1971), pp. 48-9 (s.a. 1004); cf. p. 292 (n. $49: 22$ ). 


\section{Elizabeth Boyle}

reduced to $/ \partial /$ and spelt in Old Welsh as $i$ or $e$ and in Middle Welsh usually as $y$. Furthermore, it is striking that there is an English parallel of two men being blinded, which occurred within two years of Jones's ascribed date for the blindings recorded in the Welsh chronicles. I suggest that the names found in the chronicle-entry are renderings into Welsh of the Old English names Wulfheah and Ufegeat. These were the names of the sons of Ealdorman Elfhelm who were blinded in 1006, following Ælfhelm's own murder, as part of what Simon Keynes has termed a 'palace revolution' under King Æthelred the Unready. ${ }^{4}$

The forms attested are Givlfac(b) and Gulfach, Vbiad and Vbiat. ${ }^{5}$ If we take these to be updatings of forms written in the Welsh of the time of the event (viz, late Old Welsh) we can restore Gulbac(b) or Gulfac(b) and Ubiat. If we compare the pronunciation of Old English Wulfheah, /wulfhreax/, with the Middle Welsh Gwlfach, /gulva /, the variation can be explained if we think in terms of sound substitution; that is, a speaker of late Old Welsh hearing / wulfhrea / would find it difficult to pronounce and therefore to spell, without making certain accommodations.

First, initial /wu/- would only have occurred in a grammatical environment where lenition had occurred, and a native speaker would likely have heard it as the lenited variant of /gwu/-. An initial segment /gwu/- would have simplified to /gu-/ in Old Welsh. ${ }^{6}$ Second, in Old Welsh internal -/f/- is relatively rare and usually confined to loanwords. On the other hand, internal $/ \mathrm{v} /-$, variously spelt, was very common. The sound substitution of $-/ \mathrm{v} /-$ for -/f/- would have been natural. It may have been facilitated by the Old Welsh speaker thinking that the name contained bach 'small' (lenited to fach/va $\chi$ ) or that it was a derivative in - ach of Welsh gwlf 'beak, point'. Finally the accommodation of Old English / æa/ to Old Welsh /a/ is straightforward, and especially so if perceived as the element bach. While the variation between Wulfheah and Gwlfach can be explained in terms of sound substitution in oral transmission it is far more difficult to explain it in terms of copying.

Wulfheah is a well attested name. On the other hand, the name Ufegeat is an unusual one. Apart from Elfhelm's son, I am aware of only one other reference to this name in Anglo-Saxon England, in about 1020, referring to a scireman in Essex. ${ }^{7}$ The Ufe-part of the name is not seen in other Old English personal names. ${ }^{8}$

${ }^{4}$ Keynes, The Diplomas of King Ethelred the Unread)' (Cambridge, 1980), p. 211.

5 Vryat is likely to be an error; perhaps a misreading of $V_{b}$ or of $V_{v}$ - or $V v$, possibly influenced by names such as Urien and Gwriat.

${ }^{6}$ Compare the second changes involved in Welsh gwr 'man' $<$ /gwur / < *wiro- (cf. Latin vir). See P. Schrijver, Studies in British Celtic Historical Phonolog) (Amsterdam, 1995), pp. 151-2.

7 W. G. Searle, Onomasticon Anglo-Saxonicum. A List of Anglo-Saxon Proper Names from the time of Beda to that of King Joln (Cambridge 1897), p. 465.

8 Ibid. p. 465; O. Von Feilitzen, The Pre-Conquest Personal Names of Domesda) Book (Uppsala, 1937), p. 397. For Ufegeat, von Feilitzen referred the reader to Wulfeat, under which he gives a form Viiet (ibid. pp. 397, 419-20). 


\section{A Welsh record of an Anglo-Saxon political mutilation}

In Old Welsh there was a common suffixal element -/yad/ which would have provided a ready-made replacement for Old English -/eyæat/. The variation in the Welsh spellings of $-/ \mathrm{d} /$ between final $-t$ and $-d$ is consistent with the kind of orthographical variation found in early Welsh manuscripts.

In short, these names show all the signs of being transmitted orally and undergoing regular and explicable processes of sound substitution. Oral transmission of the names does not require a bilingual (Old Welsh/Old English) scribe, but merely an Old Welsh speaker writing the names down according to his own phonological and spelling systems. It is possible, but less likely, that a bilingual scribe was copying the names and adjusting the orthography as he went, especially as he would have been adding these names to a Latin text. It is far less straightforward to account for the changes in terms of scribal copying errors.

It is likely that the reason why Wulfheah and Ufegeat were mentioned by a Welsh chronicle is because of their inheritance of lands in the Wirral and other areas of the Welsh border, left to them by their uncle, Wulfric. ${ }^{9}$ The fact that our annal occurs in the three vernacular Welsh chronicles suggests that it was from their common source. The received textual history requires that no common Welsh-language source existed; there fore, this early source must have been a Latin ancestor. It is significant, however, that the blinding of Wulfheah and Ufegeat is not mentioned in either version of Annales Cambriae (B and $\mathrm{C}$ ). It is possible that the entry was lost from Annales Cambriae or that it was added to a later common Latin source. If so, then the following stemma summarizes the history: our annal must have been incorporated from another written source into the Latin text (indicated by $\gamma^{\prime}{ }^{\prime} 1004$ ') from which the Welsh versions were separately translated (see fig. 1).

That source is unlikely to have taken its in formation from the chronicler John of Worcester, as none of the events relating to Ælfhelm which he recorded is included in the Welsh chronicles. In John of Worcester's chronicle, Elfhelm is the major character in the events of 1006 - and, having also inherited land on the Welsh borders, he too would have been of interest to the Welsh - and the blinding of his sons is a minor addition. John of Worcester, writing at Worcester in the first half of the twelfth century, described the events surrounding the blindings of Wulfheah and Ufegeat thus.

Dolosus et perfidus Edricus Streona dolum aduersus nobilem ducem Ælfhelmum oogitans apud Scrobbesbyrig magnum ei parauit conuiuium ad quod, cum inuita tus uenisset, suscepit eum Edricus quasi suus familiaris amicus. Sed insidiis preparatis, iii. uel .iiii. die conuiuii illum secum uenatum in siluam duxit, ubi cunctis circa uenationem

9. Anglo-Saxan Wills, ed. D. Whitelock (Cambridge 1930), pp. 46-51,151-60 (no. 17); Charters of Burton Abbe), ed. P. H. Sawyer (Oxford 1979), pp. 53-6 (no. 29). 


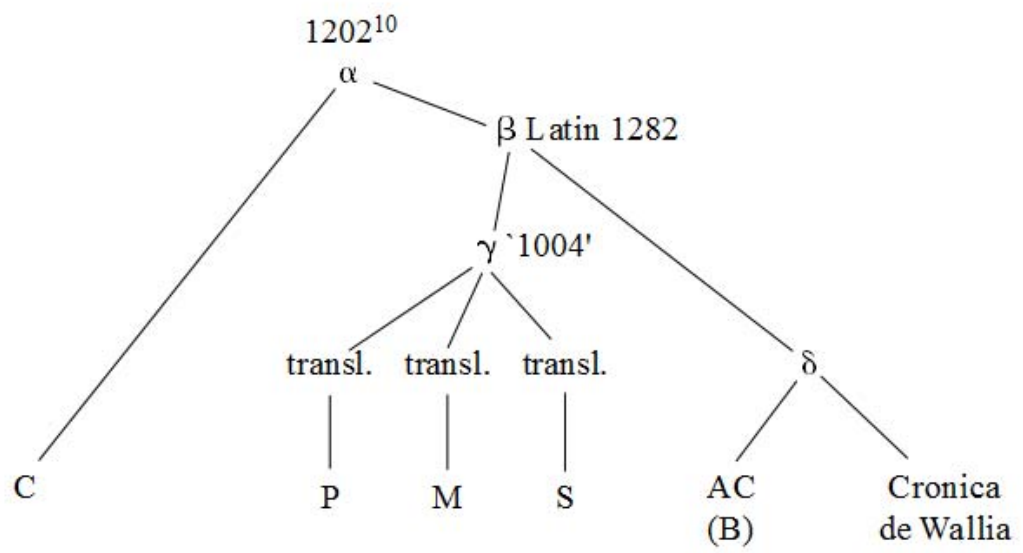

Figure 1 Proposed stemma in light of identification of '1004' annal-entry

occupatis, quidam Scrobbesbyriensis carnifex Goduuinus Porthund, id est oppidi canis, quem multo ante don is magnis multisque promissionibus pro patrando facinore excecauerat Edricus, ex insidiis subito prosiluit et ducem /Elfhelmum nefarie peremit. Paruo interiecto tempore, filii eius Wlfheagus et Vfegetus, iussu regis Egelredi apud Cocham ubi ipse tunc degebat cecati sunt.

The crafty and treacherous Eadric Streona, plotting to deceive the noble ealdorman Elfhelm, prepared a great feast for him at Shrewsbury at which, when he came as a guest, Eadric greeted him as if he were an intimate friend. But on the third or fourth day of the feast, when an ambush had been prepared, he took him with him into the wood to hunt. When all were busy with the hunt, one Godwine Porthund (which means the town dog) a Shrewsbury butcher, whom Eadric had dazzled long before with great gifts and many promises so that he might perpetrate the crime, suddenly leapt out from the ambush, and execrably slew the ealdorman Ælfhelm. After a short space of time his sons, Wulfheah and Ufegeat, were blinded, at King Ethelred's command, at Cookham, where he himself was then staying.' ${ }^{11}$

Instead, the information given in the Welsh chronicles echoes that of The Anglo-Saxon Chronicle, of which texts C, D, E and F briefly mention the blindings. Their common source was a chronicle of the reign of King Æthelred, completed soon after King Cnut succeeded to the English throne in $1016 .{ }^{12}$

${ }^{10}$ See K. Hughes, Celtic Britain in the Earl) Middle Ages (Woodbridge 1980), pp. 74-6; J. Harrison, 'A Note on Gerald of Wales and Amales Cambriae', Welsh Hist. Rev. 17 (1994/5), 252-5.

11 The Cbronicle of John of Worcester, ed. R. R. Darlington et al. (3 vols, Oxford 1995-) II, 456-9 (s.a. $[1006])$.

12 See S. Keynes, 'The Declining Reputation of King Fthelred the Unready', Ethelred the Unread): Papers from the Millenary Conference, ed. D. Hill (Oxford 1978), pp. 227-53. 


\section{A Welsh record of an Anglo-Saxon political mutilation}

Wulfeah $\mathrm{g}$ Ufegeat wæron ablænde $\mathrm{g}$ Ælfelm ealdorman ofslagen.

'Wulfheah and Ufegeat were blinded and Ealdorman \#lfhelm was killed' (1006 CD). ${ }^{13}$

Wulfeah $\mathrm{g}$ Ufegeat wæron ablende $\mathrm{g}$ Ælfelm ealdorman weare ofslagen.

'Wulfheah and Ufegeat were blinded and Ealdorman Ælfhelm was killed' (1006 E). ${ }^{14}$

Wulfeah gUfegeat wureon ablende.

'Wulfheah and Ufegeat were blinded' (1006 F). ${ }^{15}$

It is possible, therefore, that a version of The Anglo-Saxon Chronicle was a source for a common Latin ancestor of the Welsh vernacular chronicles. It is more likely, however, given the Old Welsh rendering of the names found in the Welsh chronicles, that the report came from a contemporary oral source. ${ }^{16} \mathrm{By}$ the time the Welsh chronicles as they survive today were copied, in the thirteenth, fourteenth and fifteenth centuries, it is highly unlikely that the chroniclers knew who Wulfheah and Ufegeat were. The short and incongruous nature of the entries in relation to those before and after reinforces the idea that the entry was included because it was contained in a Latin ancestor of the Welsh vernacular chronicles, rather than from any late medieval Welsh awareness of the identities of the victims. ${ }^{17}$

${ }^{13}$ The Ango-Saxan Cbronicle MS C, ed. K. O'Brien O'Keeffe, The Anglo-Saxon Chronicle: a Collaborative Edition 5 (Cambridge, 2001), 91; The Anglo-Saxon Cbronicle MS D, ed. G. P. Cubblin, The Anglo-Saxon Chronicle: a Collaborative Edition 6 (Cambridge 1996), 52.

${ }^{14}$ MS E, ed. C. Plummer, Two of the Saxon Chronicles Parallel with Sinplementary Extracts from the Others, 2 vols. (Oxford, 1892/9) I, 136.

15 The Anglo-Saxon Cbronide MS F, ed. P. S. Baker, The Anglo-Saxon Chronicle: a Collaborative Edition 8 (Cambridge 2000), 99. This sentence is not recorded in F Latin.

${ }^{16}$ It may be worth comparing the annal-entry for 1012 which records the ravaging of Menevia by Eadric (possibly Eadric Streona, mentioned by John of Worcester as being the architect of Elfhelm's death) and Ubis (Ufic?). (M) Mil a degmlyned oed oet Crist pan diUithwyt Myniw y' gan y Saesson, "nt anmen, y gan Entris ac Vbis, 'A thousand and ten was the year of Christ when Menevia was ravaged by Saxons, that is, by Eadric and Ubis' (ed. and trans. Jones, 18-19, s.a.[1012]); (P) Vil mlyned ar dec amil oed oed Kristpan di Uithy'and Eutris ac Vis Saesson Vynyw, 'One thousand and eleven was the year of Christ when Eadric and Ubis, the Saxons, ravaged Menevia' (ed. Jones, p. 13; trans. Jones, p. 11, s.a.[1012]); (S) Ammo Domini .M.XI. y' diUithwyt Myniw y' gan y' Saesson, 'Amo Domini .M.XI. Menevia was ravaged by the Saxons' (ed. and trans. Jones, pp. 48-9, s.a.[1012]); (ACB) Annus. Menevia a Saxonibus vastata est [scilicet] Edris et Ubis, Annales Cambriae, ed. J. Williams ab Ithel (London 1860), p. 22; (ACC) Menevia a Saxomibus vastatur est scilicet Edrich et Ubrich (ed. Williams ab Ithel, p. 22). Here we have sbeing used in Welsh to represent Old English $c$. Also, in the name Vis we see $V$-, again possibly representing /uve/-, in which case our second Old English name here would be Ufic. With Eadric (Eutris), the Old Welsh rendering uses $t$ for $-d-$, as we saw in the form Ubiat.

17 I would like to express my thanks to Richard Dance, David Dumville and Paul Russell for their comments and suggestions. I acknowledge the support of the Arts and Humanities Research Council in funding my research. 
